\author{
ANNA IDZIOR \\ WydZIAE HistoryCZNO-SOCJOLOGICZNY \\ UNIWERSYTET W BIAŁYMSTOKU \\ E-MAIL: ANNA_IDZIOR@OP.PL
}

\title{
OBRAZY BIAŁORUSI I BIAŁORUSINÓW W ŚWIETLE PROCESÓW GLOBALIZACYJNYCH
}

\section{Wstęp}

Globalizm i globalizacja w ciągu ostatnich kilkunastu lat stały się jednymi z terminów najczęściej używanych do opisu współczesnej rzeczywistości społecznej. Próbę zdefiniowania pojęcia globalizacji jako jeden z pierwszych podjął w 1985 roku amerykański socjolog Roland Robertson, pisząc, że jest to „zbiór procesów, które czynią świat jednym" [Sztompka 2012: 582]. W jego rozumieniu globalizacja przyczynia się do zbliżania się odległych geograficznie i kulturowo zjawisk oraz przenikania się elementów odmiennych religijnie, etycznie i kulturowo.

Globalizacja nie jest jednak terminem jednoznacznym. Według Izabeli Czai [2001: 67] „globalizacja jako termin bardzo ogólny i pojemny oznacza zarówno rozpowszechnianie, powielanie i unifikację wzorów postępowania, akceptację postaw popularnonaukowych przez media, przenikanie elementów kulturowych, mieszanie się tych elementów jak i szybkość z jaką zachodzą te procesy dzięki zdobyczom techniki (rewolucji informatycznej)".

Analizując społeczne konsekwencje zjawiska globalizacji oczywiste staje się, że procesy globalizacyjne w równym stopniu dzielą i jednoczą zarówno jednostki, jak i grupy społeczne. Problemem dzisiejszych globalnych interakcji jest m.in. napięcie pomiędzy kulturową homogenizacją a heterogenizacją, determinujące społeczne konsekwencje procesu globalizacji, uwidaczniające się m.in. w przemianach, jakie zachodzą we wzajemnych relacjach i postrzeganiu się grup społecznych, a w szczególności w stosunkach międzyetnicznych.

Jedność świata w warunkach globalizacyjnych uwidacznia się m.in. w działaniach nowoczesnych technologii oplatających ściśle świat siecią połączeń komunikacyjnych. Nowe media masowe umożliwiają ogromnej liczbie jedno- 
stek rozproszonych po całym świecie na równoczesne, wirtualne uczestnictwo w tych samych „globalnych zdarzeniach”. Efektem, a jednocześnie skutkiem ubocznym działania współczesnych mass mediów są także kreowane obrazy narodów i grup etnicznych.

Problematykę wpływu procesów globalizacyjnych na postawy i opinie wobec obcych grup i narodów oraz przemiany, jakim ulegają obrazy etniczne i narodowe porusza w Teorii Przełomu antropolog Arjun Appadurai. Stawia on tezę, iż współczesne, zglobalizowane mass media skutecznie przekształciły obszar masowego przekazu, oferując odbiorcom nowe zasoby i nowe dziedziny służące konstruowaniu wyobrażonych światów oraz wyobrażonych tożsamości. Zakłada on, iż podstawą wzajemnych wyobrażeń oraz współczesnych układów relacji pomiędzy grupami kulturowymi przestało być doświadczenie własne oraz doświadczenie członków grupy, do której przynależy jednostka.

Rozwój technologii teleinformacyjnych sprawił, iż wzrosła rola komunikacji zapośredniczonej z wykorzystaniem współczesnych mass mediów. Rozwój technologii teleinformacyjnych zwiększył także częstotliwość kontaktów społecznych na płaszczyźnie wirtualnej. Czynności, które wcześniej wymagały interakcji bezpośrednich, teraz często zachodzą za pośrednictwem sieci komputerowych, w efekcie czego są podtrzymywane i rozwijane więzi społeczne.

Globalizacja i związane z nią procesy powodują zmiany w strukturze społecznej. Następuje przejście od tradycyjnej organizacji w spójnych i wyodrębnionych grupach społecznych do luźnych i rozległych struktur sieciowych. Immanentną częścią procesu globalizacji jest postępujący proces masowych migracji i coraz mniejsze powiązanie $\mathrm{z}$ konkretnym terytorium. Jednostki tworzą transgraniczne i transnarodowe diaspory, w podtrzymywaniu których bardzo ważną rolę odgrywają media masowe. Appadurai zjawisko to nazywa mianem „ rozproszonej diaspory”.

Ten rodzaj nowoczesnej etniczności charakteryzuje zanikanie ścisłego związku pomiędzy państwem a narodem. Centra wytwarzania znaczeń, obrazów, symboli i wartości są dzisiaj eksterytorialne i wyzwolone z więzów narzucanych przez lokalność. W systemie nowej globalnej ekonomii kulturowej na znaczeniu zyskują obrazy i symbole wytwarzane, przetwarzane i rozpowszechniane przez media globalne. Opierając się na nich, kształtują się współczesne stosunki międzyetniczne i międzynarodowe.

Pojęcie wyobrażeń i obrazów zajmuje kluczowe miejsce w teorii przełomu Arjuna Appaduraia. Wyobrażenia traktuje on jako centralny punkt wszystkich form działania podmiotowego oraz kluczowy składnik nowego globalnego ładu. Appadurai proponuje rozpatrywanie funkcjonowania współczesnego świata przez pryzmat sfer rzeczywistości, które nazywa obrazami, pejzażami 
bądź treściami kulturowymi. Treści kulturowe, na których w myśl koncepcji Appaduraia opiera się nasze wyobrażenie o świecie definiuje on jako Etnoobrazy, Medioobrazy, Ideoobrazy, Finansoobrazy i Technoobrazy. Siła oddziaływania tych obrazów ma bezpośredni wpływ na kształtowanie się relacji pomiędzy jednostkami i grupami społecznymi. Wymienione krajobrazy zdaniem Appaduraia [2005: 54] „są (...) konstruktami odmienianymi przez historyczne, językowe i polityczne usytuowanie różnego rodzaju podmiotów: państwa narodowego, międzynarodowych korporacji, społeczności diaspory oraz subnarodowych grup i ruchów (religijnych, politycznych i ekonomicznych), a także grup opartych na relacjach face to face (...).

Podążając tropem teorii Arjuna Appaduraia w niniejszym artykule pragnę przedstawić zarys etnoobrazów, medioobrazów, finansoobrazów, technoobrazów i ideoobrazów wpisujących się w funkcjonujący w Polsce obraz Republiki Białoruś i narodu białoruskiego w warunkach zachodzących procesów globalizacyjnych.

\section{Obrazy Republiki Białoruś i Białorusinów w świetle Teorii Przełomu Arjuna Appaduraia}

Przemiany demokratyczne w Polsce w 1989 roku i powstanie niemal w tym samym czasie samodzielnego państwa białoruskiego, a więc wytworzenie się nowej sytuacji geopolitycznej nie miało większego wpływu na wzajemne postrzeganie się Polaków i Białorusinów u schyłku XX wieku. Wielowiekowe trwanie obok siebie obu narodów sprawiło, że wśród Białorusinów utrwalił się obraz Polski jako kraju szlachty, symbolu imperializmu oraz nośnika obcych wartości. Obraz taki kreowany był m.in. przez sowieckie podręczniki do historii, z których wiedzę czerpali młodzi Białorusini [Mironowicz, 2009:11].

W Polsce powstanie suwerennego państwa białoruskiego w 1991 roku jednostki mające wpływ na kształt opinii publicznej- głównie dziennikarze i publicyści - przyjmowali jako niezamierzony i nieoczekiwany przez nikogo rezultat przeobrażeń politycznych w Europie Wschodniej. Komentarze na temat dotyczące jakości życia politycznego, gospodarki i społeczeństwa z początku lat dziewięćdziesiątych, zamieszczane na łamach opiniotwórczych czasopism takich, jak: „Gazeta Wyborcza”, „Rzeczpospolita”, „Polityka”, „Wprost” czy „Tygodnik Solidarność" wskazywały zazwyczaj na wielki dystans dzielący Białoruś od Polski [Mironowicz 2009]. W środkach masowego przekazu w Polsce przez wiele lat upowszechniano informacje o niskiej jakości życia obywateli na Bia- 
łorusi, niezwykle niskich zarobkach, w porównaniu do Polski, wszechobecnej władzy czy zsowietyzowanym i nieukształtowanym narodowo społeczeństwie.

Zachodzące intensywnie w ciągu ostatnich kilkunastu lat procesy globalizacyjne sprawiły, że pewne elementy obrazu Republiki Białoruś w wyniku procesu masowego przepływu informacji uległy przekształceniu, a inne zostały dodatkowo umocnione.

Zwiększona w ostatnich latach mobilność przestrzenna Białorusinów sprawiła, że funkcjonujący dotychczas Etnoobraz narodu białoruskiego w Polsce uległ pewnym przeobrażeniom.

Appadurai [2005: 52-53] w Teorii Przełomu definiuje etnoobraz jako stale zmieniającą się ludzką panoramę konstytuującą świat. Na obecny etnoobraz Białorusinów w Polsce składają się w dużej mierze członkowie mniejszości białoruskiej na stałe zamieszkujący na terytorium Polski - tzw. Polscy Białorusini, Białorusini zza wschodniej granicy odwiedzający kraj w celach handlowych bądź turystycznych, młodzież białoruska kształcąca się na polskich uczelniach wyższych, Białorusini na stałe pracujące w Polsce czy też ci dopiero poszukujący pracy w kraju.

Według danych Narodowego Spisu Powszechnego z 2011 roku mniejszość białoruska w Polsce liczy 47 tys. osób. Wyróżniającym się elementem etnoobrazu tzw. polskich Białorusinów jest wyznanie prawosławne, wokół którego koncentrowała się mniejszość białoruska oraz które nierzadko deklarowali zamiast narodowości [Sadowski 1995].

W wyniku procesu asymilacji mniejszości białoruskiej na terytorium Polski oraz zachodzących procesów globalizacyjnych wyznanie prawosławne przestało być jednoznacznie kojarzone z narodowością białoruską. Badania socjologiczne prowadzone głównie na terytorium województwa podlaskiego, gdzie liczba wiernych Kościoła prawosławnego w Polsce jest największa, wskazują, że coraz częściej badani deklarują narodowość polską oraz wyznanie prawosławne. Zachodzące procesy globalizacyjne sprawiają, że kulturowe i religijne elementy dotychczas funkcjonujące obok siebie przenikają się. Małżeństwa mieszane nie są już wyjątkiem, a katolicko-prawosławne uroczystości ekumeniczne wywołują zdziwienia ${ }^{1}$.

Po 2006 roku, po wyborach prezydenckich na Białorusi, w związku z represjami wobec opozycjonistów białoruskich Polska w ramach programu im. Konstantego Kalinowskiego przyjęła na swoje uczelnie wyższe ponad 200 studentów, którzy nie mogli studiować na Białorusi ze względów politycznych.

1 http://www.radio.bialystok.pl/wiadomosci/index/id/111813 [23.04.2014], http://www.radio.bialystok.pl/wiadomosci/index/id/111772 [22.04.2014] 
Program ten realizowany jest nadal, dzięki czemu studenci białoruscy na stałe uczą się na uczelniach polskich, wpisując się w etnoobraz Białorusina w Polsce.

W środkach masowego przekazu w Polsce przez wiele lat funkcjonował obraz biednego, niezbyt rozgarniętego obywatela białoruskiego. „W reportażach telewizyjnych pokazywano nierozgarniętych kołchoźników, weteranów uginających się pod ciężarem medali lub chwiejących się osobników w pobliżu śmietników. Nawet wybitni badacze problemów społecznych Białorusi wszystkie wydarzenia w tym kraju interpretowali poprzez pryzmat «chłopskiej wizji świata»" [Mironowicz 2009:15].

Wzmożona mobilność przestrzenna Białorusinów oraz ich coraz częstsze wizyty handlowe w Polsce sprawiają, że zmianie ulega medialny obraz obywateli Białorusi. Wiąże się ona także $\mathrm{z}$ rozwojem centrów handlowych na terenie województwa podlaskiego oraz rozwojem turystyki handlowej Białorusinów. Dotychczas medialny wizerunek Białorusinów odwiedzających Polskę sprowadzał się głównie do handlarzy oferujących swoje towary głównie na białostockich bazarach oraz tzw. taniej siły roboczej.

Obecnie media coraz częściej ukazują obywateli białoruskich jako pożądanych, zwłaszcza na terenie województwa podlaskiego, klientów sklepów i galerii handlowych. Wizerunek medialny białoruskich klientów ma charakter czysto instrumentalny, mający na celu podkreślenie ich znaczenia dla polskiego handlu, zwłaszcza na terenie województwa podlaskiego, które szczególnie chętnie odwiedzane jest przez w ramach białoruskiej turystyki handlowej [Boruch 2007:5, Wysocka, Sołomacha 2012:4, Sokólska 2012:4].

Jako kolejny z elementów konstytuujących współczesny ład światowy Appadurai wymienia Ideoobrazy, które definiuje jako obrazy mające charakter polityczny i które to często wykazują powiązania z państwowymi ideologiami i kontrideologiami ruchów jawnie zorientowanych na zdobycie władzy państwowej [Appadurai 2005:56].

W ramach obrazu Republiki Białoruś dominuje ideoobraz polityki prowadzonej przez Aleksandra Łukaszenkę. Na ideoobraz polityki białoruskiej składają się m.in. takie terminy jak: reżim, dyktatura, państwo zależne od Rosji czy państwo milicyjne.

Publicyści i dziennikarze zgodnie podkreślają autorytarny charakter władzy białoruskiej określanej mianem „ostatniej dyktatury w Europie” [Medek 2008:3]. To ciekawy zabieg sprowadzający cały aparat państwowy w zasadzie do jednej osoby. Publicyści i dziennikarze charakteryzuąc Łukaszenkę, używają takich określeń, jak: „uzurpator” czy „dyktator”, a prowadzoną przez niego politykę nazywają polityczną fikcją czy bandyckim reżimem. 
Istotnym elementem ideoobrazu Republiki Białoruś jest także szereg obrazów związanych z działalnością białoruskiej opozycji politycznej funkcjonującej zarówno w Polsce, jak i na Białorusi.

Opozycyjna narracja białoruska koncentruje się wokół krytyki systemu stworzonego przez Aleksandra Łukaszenkę. Działania opozycji białoruskiej sprzyjają globalnemu rozpowszechnianiu upolitycznionych terminów i obrazów Białorusi. Narrację tę bez wątpienia cechuje „łukaszenkocentryczność”. Forma ta jest atrakcyjna dla odbiorców, ale szkodliwa dla samego postrzegania Białorusi.

Szczególnie ważnym elementem ideoobrazu Białorusi jest działalność opozycji białoruskiej na terenie Polski. Od czasu, gdy w grudniu 2010 roku, tuż po wyborach prezydenckich, białoruskie służby specjalne spacyfikowały protestującą opozycję rząd polski realizuje strategię wsparcia dla społeczeństwa obywatelskiego na Białorusi i białoruskich organizacji pozarządowych. Wsparcie to przejawia się m.in. w zwiększaniu zasięgu satelitarnego kanału Biełsat TV nadawanego w całości w języku białoruskim, przyjmowaniu na uczelnie polskie studentów białoruskich relegowanych $\mathrm{z}$ białoruskich uczelni za udziały w demonstracjach i manifestacjach antyrządowych na Białorusi, aktywne wspieranie opozycji białoruskiej czy udzielanie pomocy organizacjom białoruskim działającym w Polsce.

Przejawem polskiej polityki wobec Republiki Białoruś była również przyjęta w 2011 roku, tuż po wyborach na Białorusi, rezolucja Sejmu RP potępiająca reżim Aleksandra Łukaszenki oraz sfałszowane wybory, a jednocześnie wyrażająca wsparcie dla społeczeństwa białoruskiego i represjonowanych obywateli białoruskich [Uchwała 2011].

Działalność rządu polskiego legitymizuje ideoobraz Republiki Białoruś wytworzony przez opozycję białoruską $a^{2}$ Jednocześnie Polacy oczekują od rządu polskiego aktywnej polityki wobec władz białoruskich. Wspieranie, również finansowe, opozycji demokratycznej oraz oficjalne wspieranie organizacji pozarządowych na Białorusi, dopominanie się o prawa więźniów politycznych oraz reagowanie na naruszanie praw człowieka to działania, które, powinny prowadzić władze polskie zdaniem większości społeczeństwa [Badanie 2012].

Wiedza Polaków na temat wschodniego sąsiada dotyczy przede wszystkim kwestii ograniczania swobód obywatelskich przez rządy Łukaszenki. Terminy współtworzące ideoobrazy białoruskie są nacechowane emocjonalnie, co dodatkowo umacnia ich funkcjonowanie w świadomości Polaków. Ideoobraz

2 http://belsat.eu/pl/wiadomosci/a,15519,szef-polskiego-msz-spotyka-sie-bialoruskimi-opozycjonistami.html [19.04.2014] 
Aleksandra Łukaszenki obecnie dominuje nad innymi obrazami, przesłaniając tym samym obraz samej Białorusi oraz społeczeństwa białoruskiego.

Dominacja negatywnych terminów wchodzących w skład ideoobrazów białoruskich powoduje, że w świadomości Polaków funkcjonuje jednoznacznie negatywne wyobrażenie o stosunkach polsko - białoruskich.

Medioobrazy i ideoobrazy tworzą ściśle powiązane ze sobą konfiguracje. Medioobrazy zdefiniowane przez Arjuna Appaduraia to elektronicznie rozpowszechniane informacje i obrazy świata kreowane przez media należące do publicznych lub prywatnych grup interesu.

Środki masowego przekazu w Polsce przez wiele lat upowszechniały informacje o niskiej jakości życia obywateli Białorusi, bardzo niskich zarobkach, wszechobecnej biedzie $\mathrm{w}$ biernym, zsowietyzowanym i nieukształtowanym społeczeństwie. Medialny obraz społeczeństwa białoruskiego utrwalił się na tyle w świadomości Polaków, że nawet badacze problemów społecznych na Białorusi wszystkie wydarzenia w tym kraju interpretowali przez pryzmat funkcjonujących powszechnie stereotypów [Mironowicz 2009:15]. Ryszard Radzik słusznie zauważa, że przeciętnemu Polakowi Białoruś kojarzy się z komunistycznym skansenem, z pomnikami Lenina na głównych placach miast, społeczeństwem dążącym do integracji z Rosją oraz systemem politycznym, gdzie łamane są wszelkie prawa człowieka [Radzik 2002:196].

W końcowych latach dziewięćdziesiątych XX wieku kwestie białoruskie w mediach polskich były ukazywane z punktu widzenia tzw. niekorzystnego wyboru. Używano sformułowań: „albo idziemy do Europy, albo będzie u nas jak u Łukaszenki” lub „albo dołączymy do nowoczesnych państw, albo będziemy krajem takim jak Białoruś". Taka alternatywa była dość powszechna i skutecznie wpłynęła na upolitycznienie obrazu Republiki Białoruś w świadomości Polaków [Szegda 2009: 128].

Współczesne narracje medialne dotyczące Białorusi koncentrują się głównie wokół sytuacji politycznej tego kraju i są bezpośrednio powiązane z ideoobrazami białoruskimi. Dominują przekazy medialne dotyczące funkcjonowania państwa białoruskiego w stanie dyktatury Aleksandra Łukaszenki, działania sił opozycyjnych w stosunku do reżimu, związków politycznych pomiędzy Białorusią a Rosją oraz politycznych represji skierowanych w stronę mniejszości polskiej na Białorusi.

Pomimo częstych doniesień o demonstracjach i oporze wobec reżimu prezydenta Łukaszenki opozycyjne siły demokratyczne przedstawiane są jako słabe, podzielone i niezdolne do przejęcia władzy [Poczobut 2013].

Współczesne medioobrazy narodu białoruskiego budowane są w oparciu o istniejące dotychczas stereotypy. Obywatele Białorusi prezentowani są jako 
najbardziej spośród byłych Republik Związku Radzieckiego zsowietyzowane społeczeństwo, którego tożsamość narodowa jest bardzo słaba lub jej nie ma.

Zauważalny jest brak medialnych obrazów Republiki Białoruś związanych z turystyką czy historią tego kraju. Wyjątkiem są programy telewizyjne poruszające tematykę kulturalną i edukacyjną dotyczącą Białorusi nadawane w języku białoruskim przez dostępną drogą satelitarną telewizję Biełsat TV.

Medialny obraz Białorusi w Polsce często budzi irytację osób, które odwiedziły ten kraj i podczas podróży zaobserwowały starannie zagospodarowane pola uprawne, czyste miasta, dobre drogi, drogie samochody i pełne towarów z całego świata półki sklepowe. Trochę dłuższy pobyt pozwala dostrzec szereg sprzeczności w relacjach między państwem i społeczeństwem, które jednak nie budzą gwałtownych reakcji obywateli, a raczej ich wysiłki w kierunku przystosowywania się do warunków stanowionych przez władze [Mironowicz 2013:165].

Appadurai pisząc o współczesnych sferach rzeczywistości porusza także kwestie globalnych przepływów technologii, które definiuje jako Technoobrazy. Pod pojęciem Technoobrazów rozumie on złożone relacje pomiędzy przepływami kapitału niezależne od ekonomii, czynnika politycznego czy racjonalnego rynku.

Wydarzenia związane z stłumieniem demonstracji opozycyjnych w Mińsku w 2010 roku stały się cezurą w politycznych stosunkach między Polską a Białorusią. Nie wpłynęły one jednak na rozwijające się od 2004 roku na mocy Umowy o współpracy gospodarczej między rządem RP a rządem Republiki Białoruś o współpracy gospodarczej [Umowa]. Pomimo jednoznacznie negatywnych medioobrazów i ideoobrazów białoruskich nie wpływają one hamująco na rozwój polsko - białoruskich stosunków gospodarczych ${ }^{3}$. Dla polskich inwestorów Białoruś stała się bramą na rynek wschodni.

Polski eksport na rynek białoruski z roku na rok się zwiększa. Według szacunków Ministerstwa Gospodarki wartość dwustronnej wymiany handlowej między Polską a Białorusią wyniosła 3 mld 200 mln dolarów. Jest to o kilkanaście procent więcej aniżeli w 2012 roku [Polsko]. Pod koniec 2012 roku na Białorusi zarejestrowanych było około 531 spółek z udziałem polskiego kapitału, z czego około 280 ze 100\% udziałem polskiego kapitału, co plasuje Polskę na 9 miejscu pośród inwestorów zagranicznych na Białorusi ${ }^{4}$.

3 https://www.msz.gov.pl/pl/aktualnosci/wiadomosci/wiceminister_kacperczyk_o_wspolpracy_gospodarczej_z_bialorusia;jsessionid=45ABCD4AE096FDD9E6A1BDF5319CF328. cmsap1p?printMode=true [21.04.2014], http://forsal.pl/artykuly/788606,polacy-budowa-hotelu-w-minsku-bialorus-przed-mistrzostwami-swiata-w-hokeju.html [21.04.2014]. 
Pomimo polsko - białoruskiej współpracy gospodarczej w świadomości większości Polaków rzeczywisty technoobraz Republiki Białoruś przesłaniany jest przez polityczne medioobrazy i ideoobrazy tego kraju.

W przytaczanej Teorii Przełomu Appadurai wśród krajobrazów wpływających na nasze wyobrażenia o krajach i narodach wymienia także Finansoobrazy, w ramach których definiuje on intensywny i trudny do śledzenia ekonomiczny krajobraz związany z globalną siecią walutowych spekulacji i transferów kapitałowych.

Obraz stanu białoruskiej gospodarki konstruowany przez zglobalizowane media jest daleki od standardów wolnorynkowych z wysokim udziałem państwa. Medialny obraz Białorusi to zazwyczaj obraz zacofanego gospodarczo kraju rządzonego twardą ręką przez dyktatora będącego ostatnim w Europie sowieckiem reliktem przeszłości. Stałym elementem medialnego Finansoobrazu Republiki Białoruś jest zależność gospodarcza od Rosji i regularne wsparcie ekonomiczne z jej strony, zwane chętnie przez media "bratnią pomocą wiązaniu do sowieckiej nomenklatury. Na łamach m.in. „Gazety Wyborczej” oceniając obecną sytuacje na Ukrainie zapisano: „Kryzys na Ukrainie to dla władz Białorusi zagrożenie, a także i szansa, by wytargować od Rosji dodatkową pomoc dla kulejącej białoruskiej gospodarki” [Kubik 2014].

Dziennikarze i publicyści źródeł problemów białoruskiej gospodarki upatrują w braku reform strukturalnych i przestarzałej jej strukturze gospodarki, która blokuje usprawnienie funkcjonowania w większości nieefektywnych, białoruskich przedsiębiorstw.

Istotnym elementem Finansoobrazu Białorusi są także upowszechniane przez media informacje o niskich wynagrodzeniach Białorusinów.

\section{Podsumowanie}

Współczesne Etnoobrazy, Medioobrazy, Ideoobrazy, Technoobrazy oraz Finansoobrazy, będące składowymi całościowego obrazu Republiki Białoruś i narodu białoruskiego, są w głównej mierze konstruowane na podstawie przekazu zglobalizowanych mass mediów.

W mediach polskich dominuje ponury obraz Białorusi uciskanej przez okrutne rządy dyktatora. Informacje medialne dotyczące wschodniego sąsiada skoncentrowane są wokół polityki prezydenta Aleksandra Łukaszenki, ukazu-

5 http://www.tvn24.pl/wiadomosci-ze-swiata,2/bratnia-pomoc-putina-sypnie-dwoma-mld-euro-dla-bialorusi,382304.html [22.04.2014]. 
jąc ją jako jedyną, współczesną dyktaturę w Europie. Republika Białoruś jest przedstawiana przez pryzmat biednej, zacofanej byłej Republiki Radzieckiej. Media publiczne nie interesują się białoruską kulturą, nauką czy sztuką. We wschodniej Polsce funkcjonuje duża grupa mniejszości białoruskiej, której problematyka niezwykle rzadko poruszana jest w mediach.

Medialny obraz Białorusi oraz polityka wizowa ograniczają turystyczne wyjazdy do tego kraju, co dodatkowo utrudnia rozwój obrazów Białorusi budowanych na doświadczeniu własnym.

Ideoobrazy i Medioobrazy dominują w wizerunku Republiki Białoruś, wpływając na pozostałe składowe obrazu państwa i narodu.

Cechą charakteryzującą obrazy Republiki Białoruś i narodu białoruskiego jest, wbrew powszechnym przepływom informacji, niedoinformowanie i mglistość przekazywanych informacji. Przeciętnemu Polakowi trudno jest zrozumieć, dlaczego społeczeństwo białoruskie toleruje prezydenta, który izoluje Białoruś od Zachodu oraz ogranicza swobody demokratyczne. W literaturze polskiej bardzo mało jest opracowań specjalistycznych dotyczących faktycznej sytuacji na Białorusi, co sprawia, że mass media przejmują rolę edukatorów.

\section{Bibliografia:}

Appadurai A. (2005), Nowoczesność bez granic. Kulturowe wymiary globalizacji. Kraków Boruch A. (2007), Białorusin pilnie poszukiwany, „Kurier Poranny” 7 czerwca

Czaja I. (2001), Globalizacja, globalizm, przedsiębiorczość- szanse i zagrożenia, [w:] J. Klich (red.), Globalizacja, Kraków

Medek J. (2008), Wielkie białoruskie rozczarowanie, „Gazeta Wyborcza-Białystok” 30 września Mironowicz E. (2013), Kraina z bajki o dobrym carze, „Więź” nr 4

Mironowicz E. (2009), Sąsiedztwo polsko - białoruskie 1990-2007- oczekiwania, obawy, mity, [w:] S. Jaczyński, R. Pęksa (red.), Stosunki polsko - białoruskie. Historia i polityka, Siedlce Radzik R. (2002), Kim sq Białorusini, Toruń

Sadowski A. (1995), Pogranicze polsko - białoruskie. Tożsamość mieszkańców, Białystok

Sokólska E. (2012), Shop busy relacji Grodno-Auchan, „Gazeta Wyborcza-Białystok” 30 czerwca Szegda B. (2009), Białorusini w Polsce w świetle prac Komisji Mniejszości Nardowych i Etnicznych IV Kadencji Sejmu RP, [w:] S. Jaczyński, R. Pęksa (red.), Stosunki polsko - białoruskie. Historia i polityka, Siedlce

Sztompka P. (2012), Socjologia. Analiza społeczeństwa, Kraków

Wysocka H., Sołomacha J. (2012), Białorusini i Litwini przyjeżdzaja na zakupy, „Kurier Poranny" 12 września 


\section{Źródła internetowe}

http://www.radio.bialystok.pl/wiadomosci/index/id/111813 [23.04.2014]

http://www.radio.bialystok.pl/wiadomosci/index/id/111772 [22.04.2014]

Uchwała Sejmu Rzeczypospolitej Polskiej z dnia 25 lutego 2011 r. w sprawie wsparcia dla społeczeństwa obywatelskiego w Republice Białoruś, http://isap.sejm.gov.pl/DetailsServl et?id=WMP20110180183 [18.02.2014]

http://belsat.eu/pl/wiadomosci/a,15519,szef-polskiego-msz-spotyka-sie-bialoruskimi-opozycjonistami.html [19.04.2014]

Badanie MillwardBrown SMG/KRC (2012), Co Polacy myśla o demokracji na Białorusi?, http://wolnabialorus.pl/badania-sonda\%C5\%BCowe-\%E2\% 80\%9Eco-polacymy\%C5\%9Bl\%C4\%85-o-demokracji-na-bia\%C5\%82orusi\%E2\%80\%9D/ [21.04.2014]

Poczobut A. (2013), Białoruś patrzy na Ukrainę. Władza milczy, opozycja zazdrości, " Gazeta Wyborcza" 2 grudnia 2013, http://wyborcza.pl/1,75477,15060425,Bialorus_ patrzy_na_Ukraine__Wladza_milczy_opozycja.html [21.04.2014]

Umowa o współpracy gospodarczej między rządem RP a rządem Republiki Białoruś o współpracy gospodarczej, http://isap.sejm.gov.pl/DetailsServlet?id=WMP20060260286 [21.04.2014]

https://www.msz.gov.pl/pl/aktualnosci/wiadomosci/wiceminister_kacperczyk_o_wspolpracy_gospodarczej_z_bialorusia;jsessionid=45ABCD4AE096FDD9E6A1BDF5319CF328. cmsaplp?printMode=true [21.04.2014]

http://forsal.pl/artykuly/788606,polacy-budowa-hotelu-w-minsku-bialorus-przed-mistrzostwami-swiata-w-hokeju.html [21.04.2014]

Polsko-białoruski handel ma tendencję wzrostowa, http://inwestycje.pl/inwestycje_zagraniczne/ Polsko-bialoruski-handel-ma-tendencje-wzrostowa;229268;0.html [21.04.2014]

http://www.inwestycjenawschodzie.pl/inwestycje/bialorus [21.04.2014]

http://www.tvn24.pl/wiadomosci-ze-swiata,2/bratnia-pomoc-putina-sypnie-dwoma-mld-euro-dla-bialorusi,382304.html [22.04.2014]

Kubik A. (2014), Białoruskie tarapaty. Łukaszenka obiecuje Zachód, a gospodarka kuleje, „Gazeta Wyborcza” 27 lutego 2014, http://wyborcza.biz/biznes/1,100896,15532666,Bialo ruskie_tarapaty_Lukaszenka_obiecuje_Zachod_.html [22.04.2014] 


\section{SUMMARY}

\section{Image of the Republic of Belarus and Belarusians in the Context of Globalization Processes}

The purpose of this article is to introduce the image of the Republic of Belarus and Belarusians in the context of the "Theory of the Turn" of Arjun Appadurai. It analyzes the ethnoscapes, mediascapes, technoscapes, finanscapes and ideascapes constituting the contemporary picture of the Republic of Belarus and Belarusians. In the modern, globalized world both imaginations and symbols served an important role in inter-ethnic relations.

Contemporary images of the Republic of Belarus and Belarusian culture are constructed based on the actions of globalized mass media. The Polish media are dominated by the political image of Belarus. Belarusian society is being shown as passive in relation to Lukashenko's dictatorship.

Polish public media are not interested in the Belarusians' culture, science or art. Contrary to widespread flow of information on the globalized world, the image of the Republic of Belarus and Belarusians is characterized by vagueness and insufficient information.

\section{Keywords:}

Republic of Belarus, Belarusians, Globalism, Globalization, Ethnic Images 